\title{
07. COVID-19 Salgını Sürecinde Yükseköğretimde Türk dili ve edebiyatı eğitimi
}

\section{Halide Gamze İNCE YAKAR}

Özlem FEDAİ 2

APA: İnce Yakar, H. G.; Fedai, Ö. (2021). COVID-19 Salgını Sürecinde Yükseköğretimde Türk dili ve edebiyatı eğitimi. RumeliDE Dil ve Edebiyat Araştırmaları Dergisi, (0̈9), 77-99. DOI: 10.29000/rumelide.985285.

\section{$\ddot{0} \mathbf{z}$}

Dil, milli kimliğin şekillenmesinin mihenk taşıdır. Dille inşa edilen edebiyat ise toplumun kültürünün, dehasının ve hayal gücünün birikimidir. Dil ve edebiyat öğretimi ise bireyin şahsiyetini oluşturacak, zekâsını işletecek, ilim gücünü arttıracak ve kültürünü besleyip ayakta tutacak değerleri kazanmasını sağlamak demektir. Toplumların teşekkül şartlarından olan dilin ve edebiyatın uygun şekilde öğretimi bir manevi kültür aktarımını da beraberinde getirir. Bu sebeple dil ve edebiyat eğitiminin duygusal ve manevi bir etkileşimi de içermesi beklenir. Bu duygusal etkileşim hem dil ve edebiyat eğitimcileri açısından hem de öğrenciler açısından elzemdir. Kültürün temel dinamiklerinin nesilden nesle aktarılması, yaşatılması, geliştirilmesi dil ve edebiyat öğretiminin duygusal ve manevi etkileşimi ile gerçekleşir. Covid-19 salgınından sonra diğer tüm bölümlerde olduğu gibi Türk Dili, Türk Dili ve Edebiyatı Eğitimi, Türkçe Eğitimi, Türk Dili ve Edebiyatı bölümlerinde ve Yabancılara Türkçe Öğretimi Merkezlerinde, dersler çevirim içi olarak verilmeye başlanmıştır. Bu süreçte dil ve edebiyat eğitiminde, duygusal ve manevi etkileşim de çevirim içi olarak sağlanmaya çalışılmıştır. Araştırmamızda Covid-19 salgını sürecinde, ilgili bölümlerde görev yapan öğretim elemanlarının çevirim içi eğitim sürecine ilişkin; algı, tutum ve deneyimlerinin bağlamsallaştırılması amaçlanmıştır. Bu bağlamdan hareket ederek dil ve edebiyat öğretiminin salgın sürecindeki durumuna ıșık tutulmaya çalıșılacaktır. Nitel araștırma yöntemlerinden durum çalışması ile dizayn edilmiş, anket ve görüşmeden elde edilen veriler kullanılmıştır.

Anahtar kelimeler: Covid-19, Türk Dili ve Edebiyatı Eğitimi, Türkçe Eğitimi

\section{Turkish language and literature education in higher education during the COVID-19 epidemic}

\begin{abstract}
Language is the cornerstone of shaping national identity. Literature constructed with language is the accumulation of the culture, genius and imagination of the society. Teaching language and literature means enabling the individual to gain values that will form his personality, make his intelligence work, increase his scientific power, and feed and keep his culture alive. Appropriate teaching of language and literature, which is one of the formation conditions of societies, brings along a spiritual culture transfer. For this reason, language and literature education is expected to include an emotional and spiritual interaction. This emotional interaction is essential for both language and literature educators and
\end{abstract}

1 Dr. Öğr. Üyesi, İstanbul Okan Üniversitesi, Türk Dili ve Edebiyatı Bölümü, (İstanbul, Türkiye). gamze.yakar@okan.edu.tr ORCID ID: 0000-0002-6487-428X. [Araştırma makalesi, Makale kayıt tarihi: 02.06.2021-kabul tarihi: 20.08.2021; DOI: 10.29000/rumelide.985285]

2 Prof. Dr., İstanbul Medeniyet Üniversitesi, Türkçe Eğitimi Bölümü, (İstanbul, Türkiye) ozlem.fedai@medeniyet.edu.tr, ORCID ID: 0000-0001-7726-4096

Adres
RumeliDE Dil ve Edebiyat Araştırmaları Dergisi Osmanağa Mahallesi, Mürver Çiçeği Sokak, No:14/8 Kadıköy - ISTANBUL / TÜRKIYE 34714 e-posta: editor@rumelide.com tel: +90 $5057958124,+902167730616$
Address

RumeliDE Journal of Language and Literature Studies Osmanağa Mahallesi, Mürver Çiçeği Sokak, No:14/8

Kadıköy - ISTANBUL / TURKEY 34714

e-mail: editor@rumelide.com,

phone: +90 5057958124 , +90 2167730616 
students. Transferring, maintaining and developing the basic dynamics of culture from generation to generation takes place through the emotional and spiritual interaction of language and literature teaching. After the Covid-19 outbreak, as in all other departments, courses started to be given online in Turkish Language, Turkish Language and Literature Education, Turkish Education, Turkish Language and Literature departments and Turkish Teaching Centers for Foreigners. In this process, in language and literature education, emotional and spiritual interaction was tried to be provided online. In our research, regarding the online education process of the lecturers working in the relevant departments; It is aimed to contextualize perceptions, attitudes and experiences. Moving from this context, it will be tried to shed light on the situation of language and literature teaching during the epidemic process. It was designed with a case study, one of the qualitative research methods, and the data obtained from the questionnaire and interview were used.

Keywords: Covid-19, Turkish Language and Literature Education, Turkish Education

\section{Araştırmanın amacı}

Türkiye'deki tüm yükseköğretim kurumları, Covid-19 salgını nedeniyle 2020 yılının Nisan ayından itibaren çevirim içi eğitim vermeye başlamıştı. Araştırmamızda Türk Dili, Türk Dili ve Edebiyatı Eğitimi, Türkçe Eğitimi, Türk Dili ve Edebiyatı bölümlerinde ders veren öğretim elemanlarının çevirim içi ders sürecine ilişkin algı, tutum ve deneyimlerinin bağlamsallaştırılmasıyla hem süreçte yaşananlara dair bir durum özeti çıkarılması hem de salgın sonrasında yapılacak olan alana özgü planlamalara ve araştırmalara ışık tutulması amaçlanmıştır.

\section{Araştırmanın yöntemi}

Araştırmamızda nitel araştırma yöntemlerinden durum çalışması kullanılmıştır. Durum çalışmalarının amacı, özel bir zaman ve parametrelerle sınırlandırılmış belirli bir durumu, konuyu, problemi en iyi şekilde anlamak, derinlemesine bir anlayış sunmaktır. Durum çalışmasında sonuç, araştırmacının genel anlam çerçevesinde oluşturduğu çıkarımlardan oluşur (Creswell, 2015). Veri toplama yöntemi olarak, açık uçlu soruların bulunduğu -demografik bilgilerin sorulduğu sorular dışında- bir anket ve görüşme kullanılmıştır. Durum çalışmasıyla bağlam, ayrıntılı ve bütüncül bakış açısıyla değerlendirilerek her bağlama göre oluşan farklılıklar ve bu farklılıkların altında yatan sebepler açıklanır ve okuyucuya tasvir edilir (Saban ve diğerleri, 2016). Bu tür çalışmalarda, durumun karmaşıklığına ve özgünlüğüne, parçası olduğu bağlamla olan ilişkisine odaklanılır (Glesne, 2013). Bu nedenle salgın sürecinde 11 farklı üniversitede, Türk Dili, Türk Dili ve Edebiyatı Eğitimi, Türkçe Eğitimi, Türk Dili ve Edebiyatı bölümlerinde ve Yabancılara Türkçe Öğretimi Merkezlerinde, görev yapan 21 öğretim elemanı araştırmamıza katılımcı olarak alınmıştır. Veriler, MaxQda 2020 veri analizi yazılımı ile analiz edilmiştir. Ayrıca araştırma bulgularının yorumlanması konusunda uzman görüşü de alınmıştır. Araştırmamızın sonuçlarının, öğretim elemanlarının çevirim içi ders süreçlerine ilişkin; algl, tutum ve deneyimlerinden yola çıkılarak gelecekte yapılacak tüm akademik ve kurumsal düzenlemelere kaynaklık etmesi beklenmektedir.

\section{Araştırma grubu}

Araştırmamıza, Türkiye'deki üniversitelerde görev yapan, 7'si vakıf 14'ü devlet üniversitesinden toplam 21 öğretim elemanı katılmıştır. Katılımcıların 10'u erkek, 11'i kadındır. Grubun yaş ortalaması 42, akademik tecrübe yılı ortalaması 13'tür. Katılımcıların 2'si profesör, 2'si doçent, 7'si doktor öğretim üyesi, 2'si doktor, 7'si öğretim görevlisi ve 1'i araştırma görevlisidir. Katılımcıların 13'ü doktora, 7'si yüksek lisans, 1'i lisans

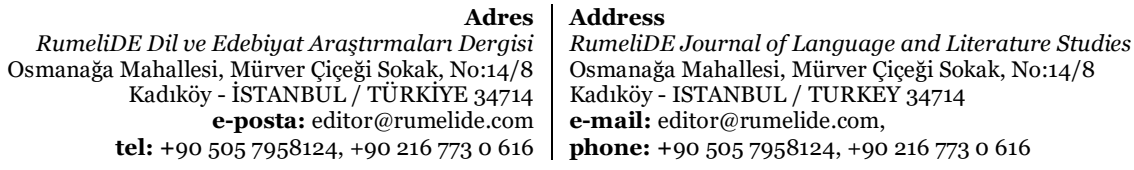


mezunudur. Türkçe Eğitimi bölümünden 10, Türk Dili Bölümünden 5, Türk Dili ve Edebiyatı Eğitimi bölümünden 2, Yabancılara Türkçe Öğretimi Araştırma ve Uygulama Merkezinden 2, Türk Dili ve Edebiyatı bölümünden 1, ilgili bölümlere ders veren temel eğitim bölümünden 1 katılımcı vardır. 21 katılımcının 9’unun idari görevi vardır. 12 katılımcının çocuğu bulunmamakta, 5 katılımcının 1 çocuğu, 4 katılımcının da 2 çocuğu bulunmaktadır.

\section{Giriş}

2019-2020 Eğitim Öğretim Yılının Nisan ayında, Covid-19 salgını nedeniyle tüm Dünya'da olduğu gibi Türkiye'de de üniversiteler kısa bir tatilin ardından çevirim içi eğitim vermeye başladılar. Bu durum Dünya'da 50 milyon, Türkiye'de yaklaşık 4 milyon yükseköğretim öğrencisinin yüz yüze eğitim alamaması anlamına geliyordu. Uzaktan eğitim ve çevirim içi eğitim deneyimlerine sahip olan kurumlar, sürece daha çabuk uyum sağlamış gözükse de; dijitalleşmeye ayrılan bütçe, dijital uyum, öğretim üyelerinin hazırbulunuşluk düzeyi, öğretim üyelerine verilen eğitim ve teknik destek gibi konularda pek çok sınırlılıklar yaşandığı bilinmektedir. Covid-19 salgını süreci öncesinde yapılan araştırmalar; uzaktan eğitim, çevirimiçi eğitim ve acil uzaktan eğitim gibi terimlerin birbirine karıştırıldığını göstermektedir. Öğretim üyesinin çevirimiçi veya acil uzaktan eğitim gibi durumlarda üstlenmesi gereken rollerden, kurumun uzaktan ve çevirim içi eğitim için kullandığı yazılıma; öğretim üyeleri arasındaki cinsiyet eşitsizliğinden vakıf üniversitelerinde görev yapan öğretim üyelerinin problemlerine; ekran başında geçirilen sürenin uzunluğundan, ölçme ve değerlendirme problemlerine kadar pek çok problemle de mücadele etme zorunluluğu doğmuştur. Ancak çevirim içi eğitim, acil ve zorunlu bir durumda, bir bulaşıcı hastalık tehlikesi altında geçen günlerde, özellikle yükseköğretimin kesintisiz bir biçimde devam etmesine katkıda bulunmuştur. Yüze yüze eğitim ile çevirim içi eğitimin karşılaştırılması; eğitim ortamlarındaki değişkenler, öğrenen ihtiyaçları, ortamın tercih edilmesindeki değişkenler gibi pek çok nedenden ötürü gerçekçi olmaz (Hodges ve diğerleri, 2020). Çalışmamızda da yüz yüze eğitim ile çevirim içi eğitim karşılaştırması yapmaktan ziyade salgın sürecinde yaşanan duruma ilişkin algl, tutum ve deneyimlerin bağlamsallaştırılarak gelecek eğitim planlamalarına katkı sunması amaçlanmıştır.

\section{Covid-19 Sürecinde Türk Dili ve Edebiyatı Eğitimi}

Covid-19 salgınından sonra diğer tüm bölümlerde olduğu gibi Türk Dili, Türk Dili ve Edebiyatı Eğitimi, Türkçe Eğitimi, Türk Dili ve Edebiyatı bölümlerinde ve Yabancılara Türkçe Öğretimi Merkezlerinde dersler çevirim içi olarak verilmeye başlanmıştı. Diğer bölümlerde yaşanan problemlere benzer problemlerin yanında, alana özgü problemler yaşandığı da bilinmektedir. Dil ve edebiyat bölümleri; değer aktarımı, duygu aktarımı, estetik-sanatsal bilinç aktarımı gibi konularda önemli kazanım alanları muhteva eder. Özellikle Türkçe ve Türk Edebiyatı alanlarındaki kazanımların yansımaları ülkemiz ve eğitim sistemimiz adına oldukça önemlidir. Dil; milli kimliğin şekillenmesinin mihenk taşıdır. Dille inşa edilen edebiyat ise toplumun kültürünün, dehasının ve hayal gücünün birikimidir. Dil ve edebiyat öğretimi ise bireyin şahsiyetini oluşturacak, zekâsını işletecek, ilim gücünü arttıracak ve kültürünü besleyip ayakta tutacak değerleri kazanmasını sağlamak demektir. Toplumların teşekkül şartlarından olan dilin ve edebiyatın uygun şekilde öğretimi bir manevi kültür aktarımını da beraberinde getirir. Bu sebeple dil ve edebiyat eğitiminin duygusal ve manevi bir etkileşimi de içermesi beklenir. Bu duygusal etkileşim, hem dil ve edebiyat eğitimcileri açısından hem de öğrenciler açısından elzemdir. Kültürün temel dinamiklerinin nesilden nesle aktarılması, yaşatılması, geliştirilmesi dil ve edebiyat öğretiminin duygusal ve manevi etkileşimi ile gerçekleşir. Covid-19 sürecinde verilen çevirim içi eğitimlerde yaşanan, alana özgü sınıllılıkların ve yararlılıkların incelenmesi ile salgın sonrası günlerde yapılacak olan eğitim programlarının ve acil eylem planlarının daha sağlam ve işlevsel biçimde planlanması sağlanabilir. Acil uzaktan eğitim

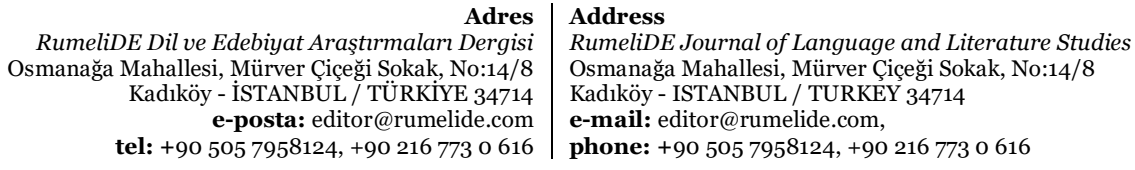


planlaması, üniversite öğretim üyelerinin yeterlilik alanının içine girmesinin yanında üniversitelerin de akademik ve idari personeli için hazırladığı profesyonel gelişim programlamasının bir parçası haline gelmelidir (Hodges ve diğerleri, 2020). Salgın sonrasında yüz yüze eğitime geçilmiş olsa bile artık hiçbir şeyin eskisi gibi olmayacağı da aşikârdır. Bu nedenle yaşananlardan ders çıkarmak, mevcut sistemi güçlendirmek ve muhtemel acil uzaktan eğitim deneyimlerine daha güçlü içerik tasarımı ve alt yapı ile hazırlanmak mümkündür.

Çalışmamız bu nedenle nitel araştırma olarak tasarlanmıştır. Katılımcıların algı, tutum ve deneyimlerine dair derin ve detaylı bilgi edinebilmek; derslerde olduğu gibi araştırmada da katılımcılarla duygusal ve manevi etkileşime girebilmek konuya daha geniş bir perspektiften bakmamızı sağlayacaktır. Salgın sürecinde, Türkçe eğitimi ve Türk Dili ve Edebiyatı anabilim dallarında uygulamalı derslerde sınırlılıklar ortaya çıkmıştır. Teorik derslerin çevirim içi işlenmesi konusunda problem gözükmese de sadece öğretmenin anlatımına bağlı veya powerpoint gösterimi ile yapılan sunumlar, öğrenci motivasyonunu sağlamada etkisiz kalacaktır. Çevirim içi uygulamalar, oyunlaștırma, interaktif çalışmalar vb. kullanmak verimliliği ve derse katılımı arttıracaktır. Öğretmenlik uygulaması, tiyatro, drama ve konuşma eğitimi gibi derslerde yaşanan sıkıntının yanı sıra duygu ve değer aktarımı, estetik bilinç kazandırma gibi konularda tüm dersler için sınırlılıklar doğmuştur. Sanatsal zevk ve estetik beğeni kazanma, çoğu zaman anın içinde şekillenen öğretim ortamlarında, beyin fırtınası, yaparak yaşayarak öğrenme, jest-mimik gibi unsurlarla kazanılır. Öğretmenlik mesleğinin, her zaman bir rol modele ihtiyaç duyduğunu ve öğretim üyesinin -tüm derslerde- mesleki bilinç kazandırma konusunda bir rol model olduğunu biliyoruz. Salgın sürecinde bu rol modellikten bütünsel olarak yararlanabilme imkânı ortadan kalkmıștır. Özellikle Türkçe ve Türk Dili ve Edebiyatı eğitiminin kalitesinde yaşanan bir düşüş, bu alandaki öğretmen adaylarının gelecekte yetiştirecekleri tüm öğrencilerin ana dili kullanma becerilerine, okuma kültürü edinmelerine, entelektüel bakış açısı kazanmalarına da etki edecektir. Türkçeyi İstanbul Türkçesinin konuşma kuralları ile konuşabilmek için öğrencilerin mevcut konuşma kusurlarının tek tek tespit edilmesi ve buna ek olarak beden dili, jest, mimik ve kürsü kullanımı gibi unsurların uygulamalı olarak denetlenmesi de önemlidir. Sözlü kültür icracısını elektronik ortamda misafir etmek veya videosunu seyrettirmek de geleneğin devamını sağlamanın bir yolu olacaktır (Yücel Çetin, 2019). Bazı kurumlar, özel bir çevirim içi eğitim yazılımı satın almak yerine Zoom, Skype vb. yazılımları kullanmışlardır. Bu yazılımlarda, tahtaya yazı yazma seçeneği olmadığı için dilbilgisi ve Osmanlıca gibi derslerde sınırlılıklar yaşanması muhtemeldir. Özellikle dilbilgisi derslerinde öğrencilerin tahtaya kalkarak, soruları cevaplaması verimliliği ve derse katılımı arttırır. Teknolojiyi, içeriği zenginleştiren bir araç olarak kullanabilmenin gerekliliği öne plana çıkmıştır. Bugün dünyada yapay zekâ tabanlı pek çok dil ve edebiyat öğretimi uygulamasını çevirim içi derslere entegre etmek mümkündür. Eğitim teknolojilerinin Türk dili ve edebiyatı bağlamında zenginleşmesi çevirim içi ders verimliliğini de arttırır ancak bu öncelikle alandaki eğitimcilerin eğitim teknolojilerine ve alan eğitiminin ihtiyaçlarına vakıf olmaları ile mümkün olacaktır.

\section{Dijital kültüre uyum}

Öğretim üyelerinin dijital okuryazarlık düzeylerinin ve teknolojiye adaptasyon becerilerinin, son derece önemli olduğu bir dönemden geçiyoruz. Öğretmenlerin dijital yeterliliklerini ele almak, pedagojiye aracılık etme yollarını anlamak eğitim liderlerine ve politika yapıcılarına ortamı anlama ve değiştirme olanağını sunar (Blume, 2020). Elbette öğretim üyesinin yaşı kadar teknolojiyi her zaman ve her yerde kullanabilme, kullanım genişliği, önceki deneyimleri, öz yeterliliği ve eğitimi de dijital okuryazarlı̆̆ın ölçüleridir. Dijital okuryazarlık seviyesinin, içinde yaşanılan dönemle de ilgisi vardır. 1946-1964 arasında doğanlar "baby boombers" yani bilgisayarın ortaya çıkışına doğanlar; 1980 sonrası doğanlar için "digital natives" yani teknolojinin içine doğan kimse terimleri de bu durumu belirtmek için kullanılmaktadır. Dijital okuryazarlık;

Adres | Address

RumeliDE Dil ve Edebiyat Araşturmalar Dergisi $\quad$ RumeliDE Journal of Language and Literature Studies Osmanağa Mahallesi, Mürver Çiçeği Sokak, No:14/8 $\quad$ Osmanağa Mahallesi, Mürver Çiçeği Sokak, No:14/8 Kadıköy - İSTANBUL / TÜRKIYE 34714 Kadıköy - ISTANBUL / TURKEY 34714 e-posta: editor@rumelide.com e-mail: editor@rumelide.com, tel: +90 505 7958124, +90 2167730616 phone: +90 505 7958124, +90 2167730616 
dijital kaynak tanımlama, erişme, yönetme, entegre etme, değerlendirme, analiz etme, sentezleme, yeni bilgi oluşturma, medya ifadeleri olușturma, dijital araçları ve olanakları uygun şekilde kullanma farkındalığı ve yeteneğidir. Dijital okuryazar bir birey yeni ve gelişen teknolojilere hızla adapte olur, birey ne kadar okuryazar ise onun için adapte olmak o kadar kolaydır ve yeni okuryazarlıklara geçmesi de o kadar kolay olur (Ng, 2012). Bilgi işlem teknolojileri okuryazarlığı ve multimedya okuryazarlığı iyi olan öğretim elemanlarının çevirim içi okuryazarlığa geçişi kolay, çevirim içi ders tasarımları da güçlü olacaktır. Salgın sürecinde ve sonrasında öğretim elemanlarının dijital okuryazarlıklarında büyük bir ilerleme yaşanması da kaçınılmazdır.

Ders tasarımı, çevirim içi bir ders vermenin en önemli basamağıdır. Öğretim üyelerinin salgın öncesindeki ders içeriklerini, dijital okuryazarlıkları ile birleştirerek çevirim içi derslere uyarlayabilmesi; bilgi işlem ve multimedya okuryazarlığını da kullanarak yenilikçi bir ders tasarımı yapabilmeleri daha da önemli hale gelmiştir. Ders tasarlamanın, öğrencinin öğrenmesini destekleyecek kaynakların ne olduğunun ve nasıl kullanılacaklarının bilgisini içerdiği unutulmamalıdır. Ders tasarımı, bilgi işidir (From, 2017). Bu kaynakların uzun bir tasarım süreciyle etkin biçimde tasarlanması; etkin öğrenme süreci, öğrenci motivasyonu, işbirlikli öğrenme, dijital süreçleri yönetme vb. alanlar düşünülerek planlanmalıdır.

Üniversiteler öğretim üyelerini çevirim içi derslere hazırlayan programlarda; eleştirel düşünme, pedagojik sorgulama, problem çözme, öğretme ve öğrenmeye dönük inanç yansıtma ile bakış açılarını dönüştürmelerine yardımcı olmalıdır. Geleneksel eğitime sırtını yaslamış olan bir öğretmeni, çevirim içi ders tasarlayan aktif bir öğretmene dönüștürmek temel amaç olmalıdır. Öğretim elemanlarının, kendi çevirim içi öğretmen kişiliğini, çevirim içi derslere bakış açısını pozitif yönde geliştirmesi için bilgi işlem birimi, işbirlikli çalışma grupları, tartışma grupları gibi topluluklar diyalog içinde tutulmalıdır (Baran ve diğerleri, 2011). Özellikle de teknolojinin derse adapte edilmesinde öğretmen eğitimi önemli bir unsurdur. Çevirim içi derslerde öğretmenlerin üstlenmek zorunda oldukları rollerin daha büyük önem arz ettiğini görmekteyiz. Koç, kolaylaştırıcı, yansıtıcı, uygulayıcı, araştırmacı, işbirlikli grup çalıșanı ve tasarımcı rolleri; öğrenci ilgisini, katılımını ve motivasyonunu sağlama da başarılı sonuçlar ortaya koyacaktır (Soetaert ve Bonamie, 1999). Covid-19 salgını, acil bir çevirim içi ders planı yapmamızı gerekli kıldı. Bu yüzden de öğretim üyeleri, salgın öncesindeki mevcut ders planlarını ve geleneksel öğretmenlik becerilerini çevirim içi derslere uygulamak zorunda kaldılar. Kurumların çoğunda, çevirim içi ders tasarımı bilgisi, dijital pedagoji eğitimi ve deneyimi olmayan öğretim üyeleri kendi yeterlilikleri ve çabalarıyla baş başa bırakıldı.

\section{Kurumsal alt yapı ve bakış açısı}

Covid-19 salgını, dünyanın her yerinde olduğu gibi Türkiye'deki üniversiteleri de hazırlıksız yakaladı. Salgın öncesinde de uzaktan eğitim merkezleri ve bilgi işlem birimlerinin koordineli çalıştığı, öğretim üyelerine dijitalleşmeye ve çevirim içi ders tasarlamaya dönük eğitimler verildiği kurumlarda, ani gelişen bu salgın sürecinin verimli geçirilmesi sağlanmıştır. Çağın gerekliliği olan dijitalleşme adımlarını atmış kurumlarda, öğretim üyelerinin ihtiyacı olan teknik donanımlar ve yazılımlar da salgın öncesinde sağlanmış durumdaydı. Kurumsal aidiyet, işbirlikli çalışma, disiplinli bir üretme ortamı, manevi bağlarla donatılmış bir çalışma ortamında ders veren öğretim elemanı çevirim içi derslere de kolay uyum sağlayacaktır. Salgın sonrasında da kurumların öğretim elemanlarının dijital okuryazarlıklarını ve çevirim içi ders tasarımı süreçlerini geliştirmek için yapılacak eğitim planlamalarına hazırlıklı olmaları gerekir.

Kurum içi araştırmalarla, öğretim elemanlarının tipolojileri, teknolojiyi kabul etme ve benimseme modelleri belirlenmelidir. Kurum içi eğitimler, bu araştırmalar sonrasında organize edilmelidir. Kurum yönetimleri tarafından öğretim elemanlarının dijital yeterliliklerinin sağlanabilmesi için finansal olarak

RumeliDE Dil ve Edebiyat Araştırmaları Dergisi $\quad$ RumeliDE Journal of Language and Literature Studies Osmană̆a Mahallesi, Mürver Ciçeği Sokak, No:14/8 $\quad$ Osmanağa Mahallesi, Mürver Çiçeği Sokak, No:14/8 Kadıköy - ISTANBUL / TURKIYE 34714 Kadıköy - ISTANBUL / TURKEY 34714 e-posta: editor@rumelide.com $\quad$ e-mail: editor@rumelide.com, tel: +90 $5057958124,+902167730616$ phone: +90 505 7958124, +90 2167730616 
desteklenmeleri ve hizmet içi kaynaklara ulaşmaları sağlanmalıdır. Öğretim elemanları arasında paylaşma ve önemseme kültürünün oluşturulmasına ön ayak olunmalı, öğretmenlerin kendi dijital pedagojilerini üzerine düşünmeleri için sorumluluk almaları sağlanmalıdır (Krumsvik, 2008).

Ülkemizde, uzaktan eğitim denildiğinde sisteme yüklenen ders materyalleri ve videolarla eğitim verilmesi akla geliyor. Oysa çağdaş uzaktan eğitimde, öğrenci merkezli ve aktif öğrenmeyi destekleyen yöntemler kullanılır. Çevirim içi eğitim, iyi bir ders tasarımıyla yüz yüze eğitimden daha etkili olabilir (Erkut, 2020). Etkili ders tasarımı süreci ve kurumsal açıdan öğretim elemanlarına tasarım desteğinin verilmesi salgın yönetiminin en önemli konularıdır.

Dünyanın pek çok saygın üniversitesi de, covid-19 sonrasında ekonomik olarak sıkıntılı zamanlar geçirmektedir. $\mathrm{Bu}$ üniversiteler, araştırma giderlerini de yabancı öğrencilerden elde edilen gelirlerle sübvanse etmekteydiler. Salgınla birlikte düşen yabancı öğrenci sayıları, üniversiteleri finansal olarak zorladı. Yükseköğretim sektörüne covid-19 nedeniyle, hükümetler tarafından yapılacak olan destek yüksek statülü kurumlara olmalıdır (Ahlburg, 2020). Yüksek puanlı öğrenci almak, yayın sayısı-kalitesi, araştırmaya ayrılan bütçe bakımından üst sıralarda olmak, hibe almanın ön koşulu olmalıdır. Türkiye'de de özellikle vakıf üniversitelerinde ekonomik kaygllar nedeniyle sözleşmelerin yenilenmemesi, maaş düşüşleri, ek ders ücretlerindeki kesintiler, kalabalık sınıflar ve özlük haklarındaki gerilemeler yaşanan sorunların sadece bir bölümüdür. Ülkemizde 11 farklı ilde, 77 vakıf üniversitesi bulunmaktadır. Birçok vakıf üniversitesinde, öğretim elemanı sayısının, YÖK'ün belirlediği asgari düzeyde tutulduğu görülmektedir (YÖK, 2021). Bu da vakıf üniversitelerinde çalışan öğretim elemanlarının daha fazla iş yükü altında olduklarını göstermektedir. Bazı vakıf üniversiteleri, salgın sürecinde devlet tarafından verilen kısmi ve kısa çalışma ödeneğinden yararlanmıştır. Bu desteği alan üniversitelerde öğretim elemanları da maaşlarının yarısını İşkur'dan almış ve sigortaları sadece kâğıt üzerinde çalışıyor gösterilen günler üzerinden yatırılmıştır. Ancak aynı öğretim elemanları mesai saati kavramının bile ortadan kalktığı zorlu çalışma koşullarında tam zamanlı olarak çalışmaya devam etmişlerdir.

Salgın sürecinde bazı kurumların ders kayıtlarını stüdyo ortamında kayıt altına almak üzere öğretim elemanlarını üniversiteye çağırması, bazı kurumların bölüm başkanlarını ve yöneticileri okula çağırması gibi durumlarda söz konusu olmuștur.

Yükseköğretim kurumlarının, mesai saatleri kavramlarına da daha esnek bir bakış açısıyla yaklaşmaları gereklidir. Evden çalışıyor olmanın verdiği zorluklardan biri de mesai saatlerine uyum sağlamaktır. Bu nedenle salgın pedagojisi çerçevesinde ele alınacak pek çok konuya ilişkin kararların ele alındığı, çözüm odaklı toplantılar yapılmalı ve standart bir salgın dönemi işleyişi oluşturulmalıdır.

Kurumsal planlamalarla okullarından çok uzun zaman uzak kalmış olan öğrencilere, üniversite hayatının sunduğu entelektüel atmosfer, akran öğrenmesi, sosyal-kültürel paylaşım, çevirim içi kantinler gibi konular için de çevirim içi veya seyreltilmiş grup aktiviteleri düzenlenmelidir.

\section{Öğrenci başarısı ve ölçme değerlendirme}

Covid-19 salgını nedeniyle yaşanan can kayıpları ve uzun süren kısıtlamalar öğrencilerin psikolojisini, öğrenme motivasyonunu ve derse katılımını olumsuz yönde etkilese de bazı öğrencilerin eve kapanma zamanlarında derslerine daha iyi odaklanmaları mümkün oldu. Öğrencilerin bazılarının evlerinde kişisel bilgisayarlarının ve internet erişiminin bulunmaması, daha önce uzaktan eğitim deneyimi yaşamamış olmak, eğitimlerinde eksiklik yaşanacağı endişesi gibi konular da öğrenci başarısına etki etmektedir (Yolcu,

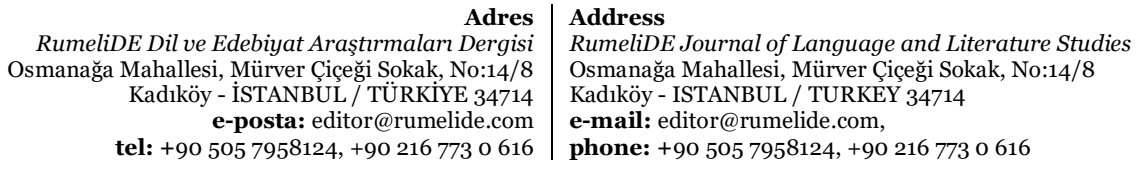


2020; Bayburtlu, 2020). Çevirim içi derslerin öğrenci penceresinden değerlendirildiği araştırmalarda, öğrenci-öğretmen iletişimi, öğretmenlerin yenilikçilik düzeylerinin geliştirilmesi, e-ders malzemelerinin tasarımı gibi konular öne çıkmaktadır (Atasoy ve diğerleri, 2020; Akgün, 2020). Öğrencilerin, öğretmenleri ile bireysel olarak yüz yüze iletişime geçemiyor oluşu, özellikle akademik başarısı yüksek öğrenciler için büyük bir sınırlılık oluşturur. Kullanılan çevirim içi eğitim yazılımlarında, sınavlardaki ölçme değerlendirme güvenirliğinin tam olarak sağlanamıyor oluşu da kurumlar ve öğretim elemanları için büyük bir endișe kaynağı oluşturmuştur. Sınav sırasında kameraların ve mikrofonların açık olması, ayna kullanımı gibi önlemler alınmaya çalışılmıştır. Çevirim içi eğitimler için gerekli alt yapının oluşturulması, planlamanın yapılması, teknik donanımın sağlanması, etkili ölçme-değerlendirme ve yönetim-denetimin sağlanması gibi konularda yaşanan problemler toplam kaliteyi de etkilemektedir. Öğrenci başarısının salgın öncesi döneme göre yüksek gözükmesinin altında; eve kapanma dönemlerinde öğrencilerin derslere odaklanması ve sınav güvenliğinin sağlanamaması gibi iki uç nokta bulunmaktadır. Ayrıca dijital uyumun son derece önemli olduğu salgın günlerinde, öğrencilerin eğitim teknolojilerine olan hâkimiyeti de akademik başarıyı etkilemiştir.

\section{Öğretim elemanı açısından cinsiyet faktörü}

Covid-19 salgını, kadınların kariyer gelişimlerinin önündeki mevcut engelleri -ev işleri, çocuk bakımı, yaşlı bakımı vb.- ek sorumluluklarla daha da arttırmıștır. Kadınların hibe başvurularında bile erkeklerle eşit değerlendirilmeye tabi tutulabilmeleri için 2,5 kat daha üretken olmaları gerektiğini; salgın sürecinde, akademik dergilerin pek çoğunda da genişleyen bir cinsiyet ayrımının göze çarptı̆̆ını biliyoruz (Malisch ve diğerleri, 2020).

Dünyada ve Türkiye'de özellikle de öğretim üyeleri ile yıllık sözleşmeler yapan vakıf üniversitelerinde özlük hakları, ücretlendirme ve çalışma koşulları konusunda, covid-19 salgını döneminde cinsiyet eşitsizliğinin arttığı bilinmektedir. Dünyada pek çok üniversitede covid-19 komitesi oluşturulmuştur. Ülkemizde de üniversitelerde bu komitelerin kurulması, bir zorunluluk olmalıdır. Salgın sürecinin etkili yönetimi ve salgından sonraki sürecin işleyişi ele alınırken, kadın öğretim üyelerinin durumları da etkili biçimde tartışılmalıdır. Özellikle vakıf üniversitelerinde, ekonomik gerekçelerle alınan önlemlerin kadın öğretim üyelerine yansımalarını araştıran çalışmalar da yapılmalıdır. Türkiye'de akademisyenlerin $\% 61,8$ 'i erkek, \%38,2'si kadındır. Pek çok akademik alanda da cinsiyet eşitsizliğine ve cinsiyetçiliğe rastlanmıştır (O'Neil ve diğerleri, 2019).

Kadınların araştırma makalelerinde başyazar olarak da yeterince temsil edilmediği, cinsiyet eşitsizliği kavramının yaşanan salgın sonrasında tüm bilimsel alanlara yansıdı̆̆ı görülmektedir. Covid-19'a ilişkin Ocak 2020-Mayıs 2020 ayları arasında yapılan yayınların sadece üçte biri kadın yazarlara aittir. Kadınların salgın sırasında araştırma yapmak için az zamanının olması da bu eşitsizliğin sebeplerinden biridir (PinhoGomes ve diğerleri, 2020).

ABD'de evli anne ve babaların ev işlerine ve çocuk bakımı için salgın öncesine göre iki kat zaman ayırdığı, yüksek eğitimli çiftler arasında bile çocuk bakımı için sorumluluk alma konusunda dengesizlik olduğu bilinmektedir (Minello, 2020). Literatüre "maternal wall" "anne duvarı" olarak giren terimde, annelik sorumlulukları olan çalışanların iş hayatında karşılaştıkları ayrımcılığa atıfta bulunulur. Salgın sürecinde bekâr annelerin, bakım gerektiren çocukla/çocuklarla evde çalışma ve ekonomik şartlar bakımından en ağır dezanvantajlı duruma sahip olduğu da ortaya konulmuştur (Alon ve diğerleri, 2020).

\section{Bulgular ve yorum}

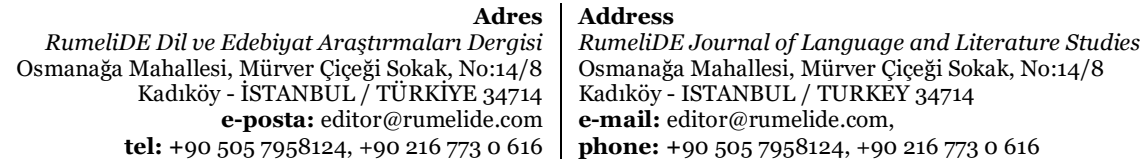

RumeliDE Dil ve Edebiyat Araşttrmaları Dergisi e-posta: editor@rumelide.com tel: +90 $5057958124,+902167730616$ 
Araştırmamızda öğretim elemanlarına açık uçlu sorular sorulmuştur. Elde edilen veriler, kimi zaman yüzdelik olarak kimi zaman da olayı tanımlayan cümlelerle anlamlı hale getirilmiştir.

Salgın öncesi uzaktan eğitim yoluyla bir eğitime, konferansa, kongreye, çalıştaya katıldınız mı?

Katılımcıların \%57'si salgın öncesinde uzaktan eğitim yoluyla verilen bir eğitime, konferansa, kongreye, çalıştaya katılmıştır.

Salgın sürecinde uzaktan eğitim yoluyla katıldığınız eğitim veya konferans var mıdır?

Katılımcıların \%95’i uzaktan eğitim yoluyla eğitim aldığını veya konferansa katıldığını belirtmiştir.

Araştırmaya katılan öğretim elemanlarının \%38'inin uzaktan eğitim kavramıyla uygulamalı olarak salgın sürecinde tanıştığı görülmektedir.

\section{Salgın öncesinde uzaktan eğitim yoluyla bir ders veya eğitim verdiniz mi?}

Katılımcıların \%76'sı da salgın öncesinde uzaktan eğitim yoluyla ders vermediğini belirtmiştir. Sonuçlar katılımcılarının büyük bölümünün salgın öncesi dönemde uzaktan eğitime dair öğretmenlik deneyimlerinin olmadığını göstermektedir.

\section{Salgın sürecinde uzaktan eğitim yoluyla katıldığınız eğitimlerden veya konferanslardan verim alabildiniz mi?}

Katılımcıların, \%57'si uzaktan eğitim yoluyla katıldığı eğitimlerden veya konferanslardan verim aldığını, \%19'u verim almadığını, \%9'u orta düzeyde verim aldığını, \%5'i emin olmadığını, \%5'i eğitime katılmadı̆̆ını belirtirken $\% 5$ 'i de sorumuza cevap vermemiștir.

Katılımcı K3, bir araştırma görevlisidir ve aynı zamanda yüksek lisans öğrencisidir. Uzaktan eğitim sürecini kendi eğitim hayatından hareketle şöyle özetlemiştir:

“Uzaktan eğitim yoluyla katıldığım yüksek lisans derslerimden aldığım verim yüz yüze yapılan derslere oranla düşü. Ders demek yalnızca bilgi aktarımı değildir. Öğrenmenin oluşması için farklı duyu ve duyguların etkisi büyük. Uzaktan eğitim süreci bunları kısıtladığı için alınan verim de buna paralel olarak azaldı."

Katılımcı K2 ise, ev ortamının dikkat konsantrasyon seviyesine olan negatif etkisine şöyle vurgu yapmıștır:

"Yeterince verim alamadım çünkü evde olmanın rahatlı̆ıyla kendimi psşkolojik olarak bir eğitime katılmış gibi hissetmedim ve eğitime konsantre olamadım."

K6 ise eğitim ortamının dikkat konsantrasyon seviyesine olan negatif etkisine şöyle vurgu yapmıştır:

"Evet, bir kere ulaşım derdiniz yok, ev ortamında, masanızda rahat rahat not alabiliyorsunuz, kameranız açık olursa zaten odaklanma probleminiz de en az düzeye iniyor. Ístekle ve merakla katıllyorsanız zaten verim alıniyor."

K2 ve K6 arasındaki söylem farklılığının, ev ortamındaki bireysel farklılıklarla ve öğrenme ortamına ilişkin kişisel bakış açısıyla ilgili olduğu görülmektedir. Öğretim elemanının evde eğitim kavramına nasıl baktığı kadar evdeki şartları da verimliliği belirleyicidir.

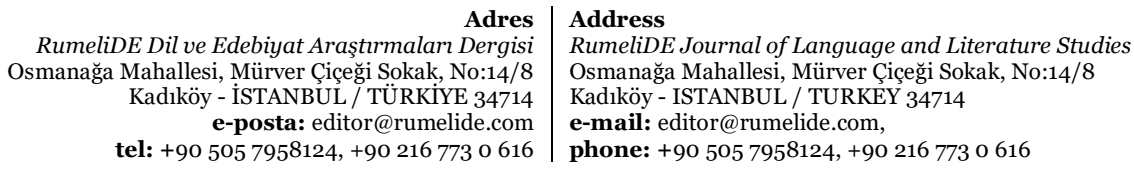


K6, K13, K21 ulaşım kolaylı̆̆ı, mekân sınırlarının kaldırılması ve pratiklik gibi unsurların verimliliği arttırdığına vurgu yapmışladır.

\section{Dijital okuryazarlık düzeyiniz sizce nasıldır?}

Katılımcıların \%10'u kendi dijital okuryazarlık seviyelerini “çok iyi”, \%62'si “iyi”, \%14'ü "orta" ve \%14'ü "kötü" olarak belirtmiştir. Öğretim elemanının kendi dijital okuryazarlık seviyesini tanımlaması, çevirim içi ders sürecindeki uyum durumunun da göstergesi olacaktır. Çevirim içi derslerde kullanılacak yazılımlar ve uygulamalar ders içeriğinin kalitesinin, öğrenci motivasyonunun ve ilgisinin artmasını sağlayacaktır. Dijital okuryazarlığını "kötü" olarak tanımlayan K10 kodlu katılımcının, cep telefonu uygulamalarına dair sorulan soruya verdiği; “Akıllı telefon kullanmıyorum.” cevabı, katılımcıların dijital uyum seviyeleri açısından büyük farklılıklar olduğunu da göstermektedir.

Katılımcılar, teknolojiye hayatlarında sırasıyla eğitim, eğlence ve kişisel gelişim alanlarında yer verdiklerini belirtmişlerdir.

\section{Uzaktan eğitimle verdiğiniz derslerde herhangi bir teknik problem yaşadınız mı?}

\%81'i teknik problem yaşadığını, \%18'i ise yaşamadığını belirtmiştir. En çok yaşanan teknik problemler sırasıyla internet kopması/yavaşlaması (\%38), kullanılan çevirim içi sistemden kaynaklanan sorunlar (\%24), elektrik kesintisi (\%10), cihaz sorunu (\%10)'dur. Y aşanan bu sorunlar dünyanın hemen hemen her yerinde uzaktan eğitimin yaşadığı genel sorunlardır. Dijital dünyaya uyum sağlayan öğretim elemanları bu sorunları daha kolay çözebilecektir.

\section{Derslerinizde teknik problem yaşadıysanız süreci nasıl yönettiniz?}

Katılımcıların derslerinde teknik problem yaşadıklarında sıklık sırasına göre ders telafisi; teknik birimlerden destek isteme; kendi tecrübesiyle sorunu yönetmek; farklı bir çevirim içi program kullanımı; e-posta, whatsap, telegram gibi iletişim yollarını kullanmak; gecikme ve ders iptali gibi çözüm yolları buldukları görülmektedir. Kurumsal alt yapının, uzak eğitim ve bilgi işlem teknolojileri bakımından güçlü olması öğretim elemanlarının yaşadıkları teknik sıkıntıların yönetilmesi, öğretim elemanına destek verilmesi açısından önemlidir. Yeni teknik detaylar öğrenmek zorunda kalan öğretim elemanlarının da kimi zaman büyük ölçüde zorlanabilecekleri unutulmamalıdır.

\section{Teknoloji ile ilgili yeni şeyler öğrenmekten keyif alır mısınız?}

Katılımcıların tamamı teknoloji ile ilgili yeni şeyler öğrenmekten keyif aldıklarını belirtmişlerdir.

Dijital okuryazarlık seviyesini “kötü" olarak tanımlayan K10, uzaktan eğitim sürecinin bir zorunluluk olarak ortaya çıkmasına vurgu yapmıştır;

"Evet, teknoloji ile ilgili yeni şeyler öğrenmekten keyif alırım ama uzaktan eğitim ani olarak gündeme geldiğinden keyif almak mümkün değildi."

Salgın öncesi dönemden bugüne teknolojiyle olan ilişkinizde neler değişti? Yeni şeyler öğrendiniz mi?

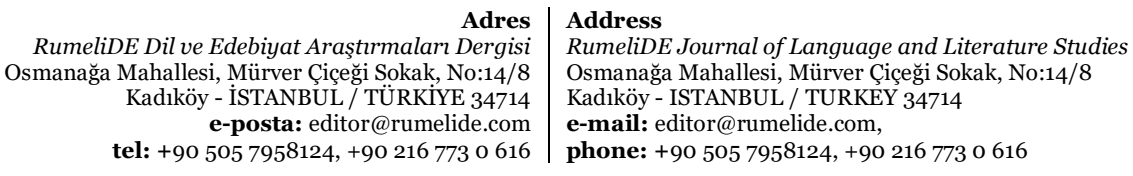

RumeliDE Dil ve Edebiyat Araşturmaları Dergis Kadıöy - ISTANBUL / TÜRKIYE 34714 tel: +90 $5057958124,+902167730616$ 
Katılımcıların tamamı, salgın döneminde teknolojiye dair yeni bilgi ve beceriler edindiklerini belirtmişlerdir. Katılımcı K3, K4, K6 ve K11, K17; Zoom, Meet, Teams, Sakai gibi çevirim içi uygulamaları kullanmayı öğrendiklerini belirtmişlerdir. Katılımcı K1 ve K15 bu öğrenme ortamının bir zorunluluk olma durumuna değinmişlerdir:

$\mathrm{K} 15$

"Teknolojiye ilgim değisşmese de daha fazla maruz kalmaya başladım."

K1

"Yeni şeyler öğrendim elbette. Ancak sürecin başında daha hevesliyken süreç ilerledikçe ekrana mahkûm olmanın verdiği sıkışıklık hissi doğmaya başladı. Binlerce eğitim, içerik, birkaç saniye ötemizde, biliyorsunuz ama artık her şey o kadar mekanik ve tek renk gelmeye başliyor ki aldı̆̆ınız eğitimleri yansıtacağınız yaşamı kurup sürdürmek güçleşiyor. Bu nedenlerle başlardaki kadar ilgili ve öğrenmeye aç bir tavır içinde olduğumu söyleyemem."

$\mathrm{K}_{7}$

“Çok çok büyük değişiklikler var tabi. Yıllardır gözü kapalı verdiğim konuları uzaktan nasıl verebilirim diye kafa patlattığım, dersler başlamadan önce diğer hocalarla birlikte sınıf kurup uygulamayı deneyimlediğimiz günler yaşadık. Teknolojiyle ilgili yeni çokça şey öğrendim."

K8

"Çevirim içi ders verme olayına olan bakış açık tamamen değişti. Hala yüz yüzeyi tercih etmekle birlikte öğrenmek için mekân birliğinin olmasının gerekmemesi hoşuma gitti."

Öğretim elemanları için uzun süre ekrana bağlı kalmak, salgın sürecinin fazla uzaması gibi konular teknolojiye dair yeni şeyler öğrenme konusunda engel teşkil etse de çevirim içi eğitim yazılımlarının kullanımı başta olmak üzere mevcut eğitim içeriğini çevirim içi derslere uyarlama gibi konularda yeni bilgiler edindiklerini belirtmişlerdir.

Türkçe ve Türk edebiyatı eğitiminin uzaktan eğitimle gerçekleştirilmesindeki sınırlılıklar nelerdir?

Tablo 1.

\begin{tabular}{|c|c|c|}
\hline & & $\mathbf{f}$ \\
\hline Öğrenci ile iletişim kurmada güçlük & & 11 \\
\hline Ölçme ve değerlendirme problemi & & 11 \\
\hline Öğrenci katılımındaki yetersizlik/katılımın denetlenemem & lesi & 4 \\
\hline Uygulamalı dersler için yetersiz eğitim ortamı & & 5 \\
\hline Sosyal, etkileşimsel bir meslek olan öğretmenlik ekrandan & öğretilemez & 3 \\
\hline Öğrenciden geri bildirim almak & & 5 \\
\hline Öğrencilerin teknolojik olanaklarındaki yetersizlik & & 2 \\
\hline Derste ilgiyi canlı tutamamak & & 3 \\
\hline Öğrencilerin kamera açmak istememesi & & 1 \\
\hline $\begin{array}{r}\text { Adres } \\
\text { RumeliDE Dil ve Edebiyat Araştrrmaları Dergisi } \\
\text { Osmanağa Mahallesi, Mürver Ciçeği Sokak, No:14/8 } \\
\text { Kadıköy - İTANBUL / TÜRKiYE } 34714 \\
\text { e-posta: editor@rumelide.com } \\
\text { tel: +90 505 7958124, +90 216 773 0 616 }\end{array}$ & $\begin{array}{l}\text { Address } \\
\text { RumeliDE Journal of Language and Literature Studies } \\
\text { Osmanağa Mahallesi, Mürver Ciçeği Sokak, No:14/8 } \\
\text { Kadlköy - ISTANBUL / TURKEY } 34714 \\
\text { e-mail: editor@ rumelide.com, } \\
\text { phone: +90 505 7958124, +90 } 216773 \text { o } 616\end{array}$ & \\
\hline
\end{tabular}




\begin{tabular}{|l|l|}
\hline Yabancılara Türkçe öğretiminde beden dilini kullanamamak & 1 \\
\hline Tahtaya yazı yazamamak & 1 \\
\hline Göz yorgunluğu & 1 \\
\hline Duygu aktarımının sağlanamaması & 2 \\
\hline Değer aktarımının sağlanamaması & 2 \\
\hline Kültür aktarımının sağlanamaması & 1 \\
\hline Estetik bilinç yaratma ortamının sağlanamaması & 2 \\
\hline
\end{tabular}

İletişim ve ölçme değerlendirme konuları, öğretim üyeleri tarafından en önemli sınırlılı olarak belirtilmiştir. Dil ve edebiyat eğitimi gibi odağında iletişim konusunun yer aldığı bir alan için öğrencilerle yüz yüze iletişim kuramamış olmak, verilen eğitimin sağlamasını yapamıyor olmak sıkça dile getirilmiştir. Ayrıca uygulamalı dersler açısından yetersiz bir eğitim ortamının bulunması ve öğrenciden geri bildirim alamamak gibi sınırılıklar da sıklık sıralamasında ikinci durumdadır. K1, K3, K7 öğretmenlik mesleğinde rol modele ihtiyaç duyulması, bilgisayar başında değil yaparak yaşayarak öğrenmenin gerekliliği, mesleki kimlik edinmede uygulamalı eğitimin önemi gibi konulara değinmiş̧lerdir.

K1

“Öğretmenin modelliğinden yoksunluk bence en büyük sinırllık."

$\mathrm{K} 3$

“Öğretmenlik gibi sosyal ve etkileşimsel bir mesleğin bilgisayar karşısında öğretilememesi. Türkçe öğretmeni adaylarının yaparak ve yaşayarak yetişmelerinin sekteye uğraması bu sınırlllıkların başında gelmektedir."

K7

“Sosyal bilimlerin sahasına girmeleri sebebiyle diğer alanlara (sağlık bilimleri, mühendislik vb.) göre teoride çok da ciddi negatif etkileri olacağını düşünmesem de eğitim fakültesinde görev yaptığım için uygulamada ve mesleki bakış kazanma (benim tabirimle öğretmenlik gömleği giymede) alanında ciddi eksikliklere sebep olacaktır."

Doçent K11, görüşmede, konunun mesleki boyutuna daha detaylı biçimde değinmiştir;

“Öğretmen adaylarının öğretecekleri şeyleri uygulamalı olarak uygulamaları gerekiyor. Nasıl yapacaklarını göstermeniz, süreç içinde ortaya çıkacak sorunları daha da yaşayarak görmeleri gerekiyor. Konunun üzerine düşünmeleri gerekiyor, birbirleriyle duygu ve düşünce alışverişinde bulunmaları gerekiyor. Bunlar eksik kalıyor. Bunlar olmayınca da öğretmenlik boyutu bana kalırsa eksik kalıyor."

\section{Türkçe ve Türk edebiyatı eğitiminin uzaktan eğitimle gerçekleştirilmesindeki yararlılıklar} nelerdir?

Tablo 2 .

\begin{tabular}{|c|c|c|}
\hline & & f \\
\hline Mekândan bağımsız bir eğitim ortamı & & 5 \\
\hline Zaman tasarrufu & & 4 \\
\hline $\begin{array}{r}\text { Adres } \\
\text { RumeliDE Dil ve Edebiyat Araştrrmaları Dergisi } \\
\text { Osmanağa Mahallesi, Mürver Çiçeği Sokak, No:14/8 } \\
\text { Kadıköy - İTANBUL / TÜRKiYE } 34714 \\
\text { e-posta: editor@rumelide.com } \\
\text { tel: +90 505 7958124, +90 } 216773 \text { o } 616\end{array}$ & $\begin{array}{l}\text { Address } \\
\text { RumeliDE Journal of Language and Literature Studies } \\
\text { Osmanağa Mahallesi, Mürver Çiçeği Sokak, No:14/8 } \\
\text { Kadaköy - ISTANBUL / TURKEY } 34714 \\
\text { e-mail: editor@rumelide.com, } \\
\text { phone: +90 505 7958124, +90 } 216773 \text { o } 616\end{array}$ & \\
\hline
\end{tabular}




\begin{tabular}{|l|l|}
\hline Dijital kaynakların, uygulamaların kullanımını ve paylaşımını kolaylaştırıyor & 4 \\
\hline Uzaktan eğitimin yararlı̆ı̆ı yoktur & 2 \\
\hline Salgın şartlarında sağlı̆ımızı korumak & 2 \\
\hline Öğrencilerin sunum yapma becerilerine destek olması & 1 \\
\hline Derse katılımın kolay olması & 1 \\
\hline Materyal çeşitliliğine imkân vermesi & 1 \\
\hline Pratiklik & 3 \\
\hline Çağın şartlarına uyum sağlamayı kolaylaştırması & 1 \\
\hline Derse ilgiyi arttırma imkânı vermesi & 3 \\
\hline
\end{tabular}

Salgın koşullarında çevirim içi ders ortamını kullanarak bir araya gelebilmek, öğretim elemanlarına göre uzaktan eğitimin en büyük yararlılı̆̆ıdır. Zaman tasarrufunun sağlanması ve dijital kaynakların kullanımının ve paylaşımının kolaylaşması da en sık belirtilen yararlılıklardır.

\section{Türkçe ve Türk edebiyatı eğitiminde uzaktan eğitimle gerçekleştirilmesinde en çok hangi derslerde sınırlılık yaşanacağını düşünüyorsunuz?}

Tablo 3.

\begin{tabular}{|l|l|}
\hline & f \\
\hline Öğretmenlik uygulaması/ Okul Deneyimi & 7 \\
\hline Yazılı Anlatım & 5 \\
\hline Sözlü Anlatım/Konuşma Eğitimi & 5 \\
\hline Osmanlıca & 4 \\
\hline Dilbilgisi & 4 \\
\hline Okuma Eğitimi & 3 \\
\hline Tiyatro ve Drama & 2 \\
\hline Yabancılara Türkçe Öğretimi & 1 \\
\hline Dilbilim & 1 \\
\hline Dinleme & 1 \\
\hline Tüm derslerde & 1 \\
\hline Tahta kullanılacak tüm derslerde & 1 \\
\hline
\end{tabular}

Türk Dili, Türk Dili ve Edebiyatı Eğitimi, Türkçe Eğitimi, Türk Dili ve Edebiyatı bölümlerindeki derslerin büyük bölümü teorik derslerden oluşsa da özellikle öğretmenlik mesleğinin uygulamalı alanlarını ilgilendiren okul deneyimi, konuşma eğitimi, yazılı anlatım gibi derslerde uzaktan eğitimin sınırlılıklar teşkil ettiği görülmektedir. Osmanlıca, dilbilgisi gibi derslerde de interaktif çalışmalar yapmanın gereklilikleri de uzaktan eğitimde çeşitli sınırlamalar yaratmaktadır.

Katılımcılar görüşmede, uygulamalı derslerde yaşanan problemlerin yanında dilbilgisi ve sözlü anlatım derslerinde yaşanan sıkıntılara da değinmişlerdir;

Doktor öğretim üyesi, K6,

Adres

RumeliDE Dil ve Edebiyat Araştırmaları Dergisi Osmanağa Mahallesi, Mürver Çiçeği Sokak, No:14/8 Kadıköy - ÍSTANBUL / TÜRKIYE 34714 e-posta: editor@rumelide.com tel: +90 $5057958124,+902167730616$
Address

RumeliDE Journal of Language and Literature Studies

Osmanağa Mahallesi, Mürver Çiçeği Sokak, No:14/8

Kadıköy - ISTANBUL / TURKEY 34714

e-mail: editor@rumelide.com,

phone: +90 505 7958124, +90 2167730616 
"Ben gramer derslerinden zorlandım çünkü sınıf içinde bir uygulama yapabiliyorduk. Yeri geldiğinde tahtada ya da daha fazla örnek çözümlemesi gibi...” cevabını vermiştir.

\section{Doktor, K 13}

"Sözlü anlatım kısmında zorlandım. Eğitim fakültelerinin sözlü anlatım dersinde konularımız; diksiyon, beden dili, artikülasyon, vurgu ve tonlama çalışmaları işte bunları yaparken..."

Türkçe ve Türk edebiyatı eğitiminde uzaktan eğitimle gerçekleştirilmesinde en çok hangi derslerde yararlılık sağlanacağını düşünüyorsunuz?

Tablo 4.

\begin{tabular}{|l|l|}
\hline & f \\
\hline Teorik derslerde & 3 \\
\hline Yararlılık yoktur & 3 \\
\hline Konuşma Eğitimi & 2 \\
\hline Ĕgitim Teknolojileri & 2 \\
\hline Metin Tahlili & 2 \\
\hline Okuma Eğitimi & 2 \\
\hline Yeni Türk Edebiyatı & 2 \\
\hline Halk Edebiyatı & 2 \\
\hline Dilbilgisi & 1 \\
\hline Çocuk Edebiyatı & 1 \\
\hline Eski Türk Edebiyatı & 1 \\
\hline Dinleme Eğitimi & 1 \\
\hline Turkish Writing (Yazma) & 1 \\
\hline Dersi alttan alıp derse devam etme zorunluğu olmayan öğrencilerin dersleri & 1 \\
\hline
\end{tabular}

Teorik ağırlıklı derslerin çevirim içi olarak verilmesinde yararlılıklar olduğu belirtilmişlerdir. Ayrıca eğitim teknolojileri dersinin ilk kez konuşulduğu bölüm de yararlılık bölümü olmuştur.

Dil ve edebiyat öğretimi için (derste, ders sonrasında, ders malzemesi hazırlamak için) kullandığınız dijital uygulamaların isimlerini yazabilir misiniz?

Tablo 5.

\begin{tabular}{|l|l|}
\hline & f \\
\hline Microsoft Office & 5 \\
\hline Padlet & 5 \\
\hline Powerpoint & 7 \\
\hline Kahoot & 5 \\
\hline Youtube & 3 \\
\hline Edmodo & 3 \\
\hline
\end{tabular}

RumeliDE Dil ve Edebiyat Araştırmaları Dergisi $\quad$ RumeliDE Journal of Language and Literature Studies Osmanağa Mahallesi, Mürver Çiçeği Sokak, No:14/8 $\quad$ Osmanağa Mahallesi, Mürver Çiçeği Sokak, No:14/8 Kadıköy - İSTANBUL / TÜRKIYE 34714 Kadıköy - ISTANBUL / TURKEY 34714 e-posta: editor@rumelide.com $\quad$ e-mail: editor@rumelide.com, tel: +90 $5057958124,+90216773$ o 616 phone: +90 505 7958124, +90 216773 o 616 


\begin{tabular}{|c|c|}
\hline Blackboard & 2 \\
\hline Prezi & 2 \\
\hline Word & 2 \\
\hline Google Forms & 2 \\
\hline Glogster & 1 \\
\hline Telegram & 1 \\
\hline Powtoon & 1 \\
\hline Edpuzzle & 1 \\
\hline Socrative & 1 \\
\hline Google Classroom & 1 \\
\hline Wiki Lala & 1 \\
\hline Foxit Fantom PDF Editör & 1 \\
\hline Adobe Reader DC & 2 \\
\hline Liveworksheet.com & 1 \\
\hline Quizlet & 1 \\
\hline Yandexdisk & 1 \\
\hline Google Drive & 1 \\
\hline AHD altyazı programları & 1 \\
\hline Moviemaker & 1 \\
\hline Zoom & 1 \\
\hline Teams & 1 \\
\hline Puzzle Maker & 1 \\
\hline Storybird & 1 \\
\hline Make Beliefs Comics & 1 \\
\hline SpiderScribe & 1 \\
\hline Paint & 1 \\
\hline Excel & 1 \\
\hline
\end{tabular}

Çevirim içi derslerde, ders sonrasında, ders malzemesi hazırlamak için kullanılan dijital uygulamaların sorulduğu soruya 28 uygulama ismi ile cevap verilmiştir. Uygulamalar dışında temel Microsoft uygulamalarının (Word, Powerpoint, Paint, Excel) da sayıldığı görülmüştür. Sınıf içinde araştırma, soruşturma yapmak, veri depolamak ve paylaşmak, test hazırlayıp öğrencilere göndermek gibi amaçlarla kullanılan uygulamalar da vardır. Öğrencilerle bir araya gelmek için kullanılan sanal sınıf ve toplantı uygulamaları, öğrenci ile iletişim içinde olabilmek için ses, görüntü ve anlık ileti servisleri de bu uygulamalar arasındadır. Video, animasyon, karikatür ve bulmaca oluşturma ve düzenleme, etkileşimli materyal geliștirme konularında kullanılan uygulamalar da vardır. Ayrıca öğrencilerin yazılı anlatım becerileri takip etmek, öğretilmek istenilen konuların tekrar edilmesini sağlamak gibi amaçlarla da uygulamalar kullanılmaktadır. Osmanlı Türkçesi ile yazılmış metinlerin arşivlendiği bir dijital kütüphane uygulaması da söylenmiştir. 
Kadın öğretim elemanları (11 kişi) bu soruya toplam 37 uygulama ile erkek öğretim elemanları (10 kişi) 30 uygulama ile cevap vermiştir. Kadın öğretim elemanları daha fazla dijital uygulama kullanmaktadır.

Aynı soruya 26-40 yaş aralığındaki öğretim elemanları (11 kişi) 47 uygulama ile, 40-60 yaș aralığındaki (10 kişi) 25 uygulama cevap vermiştir. 26-40 yaş aralığındaki öğretim elemanları, 40-60 yaş aralığındakilere göre neredeyse iki kat fazla dijital uygulama kullanmaktadırlar.

\section{Kişisel eğitiminiz için kullandığınız cep telefonu uygulamalarının isimleri nelerdir?}

Tablo 6.

\begin{tabular}{|c|c|}
\hline & $\mathrm{f}$ \\
\hline Zoom & 5 \\
\hline Youtube & 4 \\
\hline Teams & 3 \\
\hline Dualingo & 2 \\
\hline Udemy & 2 \\
\hline Wordup & 1 \\
\hline Lingua Leo & 1 \\
\hline TDK Türkçe Sözlük & 1 \\
\hline Kütüphanem & 1 \\
\hline Sudoku & 1 \\
\hline Kelimelik & 1 \\
\hline Watsapp & 1 \\
\hline Edmodo & 1 \\
\hline Sakai & 1 \\
\hline Cambly & 1 \\
\hline Google Meet & 1 \\
\hline Academia & 1 \\
\hline Researchgate & 1 \\
\hline Issue & 1 \\
\hline Tedx & 1 \\
\hline BBC Learning English & 1 \\
\hline
\end{tabular}

Kişisel eğitimleri için cep telefonlarında kullanılan dijital uygulamalar sorulduğunda; sohbet, iletişim ve sanal sınıf uygulamalarının yanı sıra sözlük, kütüphane ve dil eğitimine ilişkin uygulamaların belirtildiği görülmektedir.

Salgın öncesi verdiğiniz derslerdeki öğrenci akademik başarısını, salgın sürecindeki öğrenci akademik başarısıyla karşılaştırırsanız neler söylemek istersiniz?

Katılımcıların \%67'si salgınla birlikte akademik başarının düștüğü söylemiștir. Akademik başarının düştüğünü söyleyen katılımcıların \%33'ü ise çevirim içi sınavların ölçme ve değerlendirme problemine dikkat çekmiştir. Katılımcıların \%14'ü ise salgın öncesi ve salgın sürecindeki akademik başarı arasında

Adres $\mid$ Address

RumeliDE Dil ve Edebiyat Araştırmalar Dergisi $\quad$ RumeliDE Journal of Language and Literature Studies Osmanağa Mahallesi, Mürver Çiçeği Sokak, No:14/8 Osmanağa Mahallesi, Mürver Çiçeği Sokak, No:14/8 Kadıköy - İSTANBUL / TÜRKIYE 34714 Kadıköy - ISTANBUL / TURKEY 34714 e-posta: editor@rumelide.com e-mail: editor@rumelide.com tel: +90 505 7958124, +90 2167730616 phone: +90 505 7958124, +90 2167730616 
farklılık olmadığını belirtirken, salgın sürecinde çevirim içi derslerden sonra akademik başarının arttığını söyleyen öğretim elemanı bulunmamaktadır.

Görüşmelerde de, ölçme değerlendirmede yaşanan problemlerin akademik başarıya sonuçlarını manipüle ettiği söylenmiştir. Sınav güvenliğinin sağlanamamasına sıkça değinilmiş ve Whatsapp ve Discord gibi uygulamalar yoluyla sınavlarda kopya çekildiğine değinilmiștir (K3, K11).

Salgın öncesi dönemden bugüne teknolojiyle olan ilişkinizde neler değiști? Yeni şeyler öğrendiniz mi?

1 katılımcı dışında diğer tüm katılımcılar salgın döneminde teknolojiye dair yeni bilgi ve beceriler edindiklerini belirtmişlerdir. Araştırmamızda kimi öğretim üyeleri kurumlarından teknik eğitim desteği alamadıklarını, kimileri de çevirim içi uygulamalarla ilgili kişisel eğitimler aldıklarını belirtmişlerdir.

K12

"Çevirim içi ve uzaktan eğitimde hangi platformları ve nasıl kullanabilirim gibi konferanslara katıldım. Bunları derslerimde kullanabilmem açısından bilgilendirici oldu."

\section{Salgın günlerinden sonra da çevirim içi eğitim vermek ister misiniz?}

Katılımcıların \%62'si bu soruya "evet" cevabı verirken, \%19'u "hayır", \%19'u da "Bazı dersler için vermem mümkün olabilir.” Cevabını vermiştir.

K8

"Kişisel olarak pandemi öncesi uzaktan eğitime çok ciddi karşıydım. Ama süreçte sadece mecburiyetten değil aynı zamanda pandemi sonrasında da olabilecek bir seçenek olarak görmeye başladım. Bu tür ders işleme durumunu ve kendimi geliştirmeye çalıştım."

\section{Dijital donanımınız ve yazılımlarınız kurumunuz tarafından mı tahsis edildi?}

Katılımcıların \%52'si kurumu tarafından tahsis edilen cihazları kullanırken, \%42'si kendi cihazlarını kullanmaktadır.

\section{Salgından sonra yeni bir bilgisayar veya tablet edindiniz mi? Neden?}

Katılımcıların \%76'sı bu soruya “hayır", \%24'ü evet cevabını vermiștir.

\section{Çevirim içi ek derslerinizin ödemelerini salgın öncesindeki koşullarda mı aldınız?}

Katılımcıların \%57'si “Evet”, \%29'u “Hayır" cevabını vermiştir.

"Hayır" cevabını verenler arasında ek ders ödemelerini gecikmeli alanların sayısı \%10, ek ders ücretinin yarısını alabildiğini söyleyenlerin sayısı \%10, sınıfların birleștirilmesinden doğan bir ücret düşüşü yaşadıklarını söyleyenlerin sayısı \% 5 'tir. Ek ders ücretinin geç yatırıldığını ve ücretin yarısını alabildiklerini söyleyen öğretim elemanları bir vakıf üniversitesinde görev yapmaktadırlar.

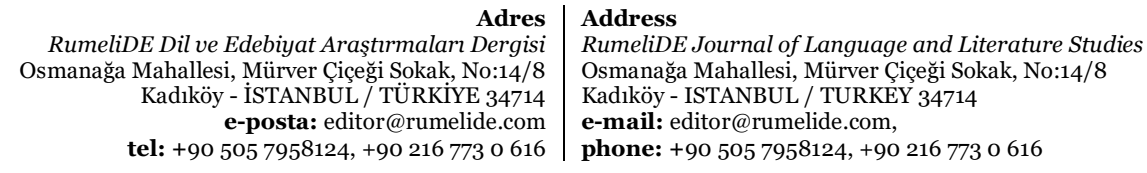




\section{Çevirim içi eğitim sürecinde, cinsiyet faktörünün öğretim üyesinin başarısını etkileyen unsurlardan biri olduğunu düşünüyor musunuz? Süreç sizi nasıl etkiledi?}

Katılımcıların \%71'i "Hayır” cevabını verirken, \%29'u evet cevabını vermiştir. Çalışmamızda da K2, K4, K7, K11, K13, K21 de kadın akademisyenlerin "annelik" sorumluluklarına da değinmişlerdir.

\section{K4}

"Hem anne hem öğretmen hem aş̧̧ı hem araștırmacı hem temizlikçi vb. olmak çok zordu. Yayın yapamadım."

\section{K21}

"Yalnız yaşadığım için bu durum beni etkilemedi. Ancak deneyimlerini gözlemlediğim evli ve çocuklu arkadaşlarımın iş yükünü arttırdı."

\section{K13}

"Kadın akademisyenler çocukları da evde olduğu için evden derse girmek durumunda kaldılar. Fakat erkek akademisyenler okuldaki odalarında derse girdi. Onlar sosyal olarak etkilenmediler. Derslerinin olmadiğı zamanda akademik çalışmalarını da devam ettirdiler. Fakat kadın akademisyenler ev ve çocuk sorumluluğuyla birlikte derslerini yürütmeye çalıștılar."

K7

"Kadın olmanın sorumlulukları ve güzellikleri çevirim içi/çevirim dışı her şekilde sizi buluyor. Evden dersleri yaptığımız süreçte çok daha yorucu ve yıpratıcıydı benim için. Bunda cinsiyet en önemli faktör."

Katılımcılar yapılan görüşmelerde cinsiyet eşitsizliği konusuna ilişkin daha detaylı bilgi vermişlerdir.

\section{K13}

"Bu durum bizim kanayan yaramız, toplumun kanayan yarasl, maalesef akademinin de kanayan yarası... Bu pandemi erkek akademisyenlerin işine yaradı. Onlar evde çocukların başında kalmadılar. Kadınlar evde kaldl, erkekler derslerine okulda girdiler. Akademik çalışmalarına devam ettiler. Bizim ister istemez önceliklerimiz farklıydı, evde olunca fedakârlık yapamayacağımız konular vardı; anneliğimiz gibi... Önceliğimiz bu olunca hep kendimizden fedakârlık yaptık. Akademik çalışmalarımızı hep dinlenme saatinde yapmak zorunda kaldık. Geceleri çocukları yatırdıktan sonra veya sabah erkenden onlar daha uyanmadan bir şeyler yapmaya çalıștık ama erkek arkadaşlar evde kalmanın dezavantajını yaşamadılar. Pandemiyi avantaja dönüştürdüler."

\section{Çevirim içi derslerinizdeki öğrenci performanslarından memnun musunuz?}

Katılımcıların \%76'sı "Hayır" cevabını verirken, \%24'ü evet cevabını vermiştir.

\section{K8}

"Bazı gençler beni çok şaşırttı ve katılımcı olmaları mutlu etti. Bazılarıysa sadece derse girip belki ekran başında bile değillerdi. Buna birkaç kez şahit oldum. O nedenle bu soruya evet ya da hayır diyemem. Ben elimden geleni yaptım. Gerçek talebeler alacağını aldı.”

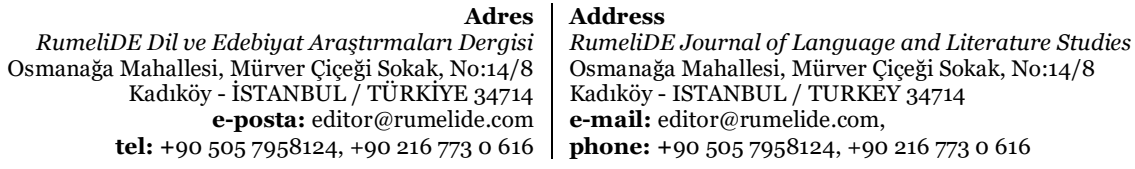


"Kısmen, öğrencilerin teknolojik imkânları onları zorladı."

\section{Salgın öncesinde ve salgın sürecinde bir günde bilgisayar başında geçirdiğiniz ortalama süre nedir?}

Katılımcıların salgın öncesinde bir günde bilgisayar başında geçirdiği ortalama süre 4 saat iken, salgın sonrasında bu süre ortalama 8 saate çıkmıştır.

\section{K4}

“Uzun süreli göz yorgunluğu”

\section{Salgın sürecini, kurumunuzun başarılı bir şekilde yürüttüğünü düşünüyor musunuz? Neden?}

Katılımcıların \%48'i “Evet”, \%24'ü “Hayır”, \%14'ü “Kısmen”, \%10’u “Başta hayır ama şimdi evet” cevaplarını vermişlerdir. Katılımcılar kurumları tarafından kullanılan çevirim içi eğitim yazılımına dair eğitim alamamaktan, insan hayatına saygıya, teknik alt yapı ve malzeme eksikliğinden, idari çalışanlara ve farklı birimlere uygulanan çifte standarda vurgu yapılmıștır.

K3

Kurumumuzca bize lisanslı bir yazılım sunuldu ve sınırlı bir șekilde nasıl kullanacă̆ımızla alakalı bir eğitim aldık ancak yazılımsal hataları ve pek çok detayı kullanırken öğrenmiş olduk.

K1

Kesinlikle hayır. Süreçte öncelik insan hayatı olmalıydı. Bu yönde hiçbir değer hissetmedim. Her ne kadar hesapta olmayan bir durumla karşı karşlya olsak da vizyoner kurumların adaptasyon güçleri kriz yönetimlerindeki başarıyı göstermiş oldu. Benim kurumumda bir öngörü yetisi eksikliği ve insan hayatına, değerlerine saygisızlık söz konusu.

K20

Hayır, teknik alt yapı ve materyal eksiliği bu süreçte ders veren öğretim görevlilerini kısıtladı̆̆ını düşünüyorum.

K2

Hayır düşünmüyorum. Bu süreçte hocaların ve idari çalışanların özlük haklarını gözettiğini düşünmüyorum. Özellikle idari çalışanlar konusunda adaletsiz bir çalışma sistemi uyguladıklarını düşünüyorum. Bazı birimler ve yöneticiler uzaktan çalışıp kendilerini riske atmazken bazı çalışanların kuruma gidip yerinde çalışmaya zorlanmaları çifte standarttır. İnsan hayatı söz konusu olduğunda mevkilerin, makamların önemi yoktur.

Salgın öncesinde de çalışanlarının ihtiyacı olan teknik donanımları sağlamış ve dijital teknolojilere ekonomik yatırım yapmış kurumlarda da salgın sürecine geçiş kolay olmuştur.

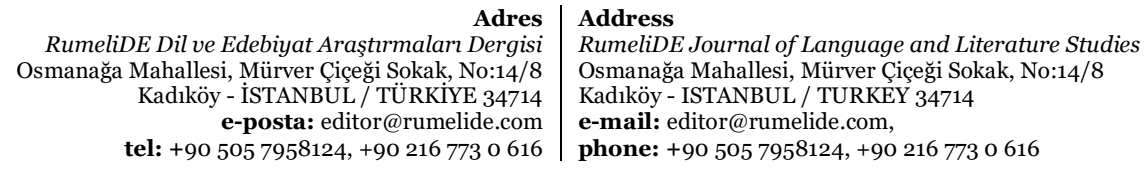




\section{Salgının başlamasından sonra kurumunuzda, özlük haklarınızla ilgili bir gerileme yaşadınız mı? Yaşadıysanız bunlar nelerdir?}

Araştırmamızda vakıf üniversitelerinden katılımcıların büyük bölümü salgın sürecinde özlük hakları konusunda gerileme yaşamadıklarını belirtmiştir.

Katılımcıların \%62'si "Hayır" cevabı verirken \%29'u "Evet" cevabı vermiștir. "Evet" cevabı veren katılımcıların özlük haklarındaki gerilemeler şöyledir; eksik ücretlendirme, kısa/kısmî çalışma ödeneğinden faydalanan bir kurum olması nedeniyle maaşın yarısının farklı zamanlarda İşkur ve üniversite tarafından yatırılması, sigorta priminin salgın başından beri yatırılmaması, sigorta priminin 10 gün üzerinden yatırılması, ek ders ücretlerinin yarıya indirilmesi, mesai saatlerinin ortadan kalkması, maaşın sözleşmede yazan miktarın altında kalması, ücretlerin geç yatırılması.

Sadece salgın süreciyle ilgili olmamakla birlikte Yükseköğretim Kurumunun, özellikle vakıf üniversiteleri çerçevesinde öğretim üyelerinin özlük haklarının korunması açısından çalışmalar yapması ve denetimleri sıkılaştırmaları da gerekmektedir. Kurumsal aidiyetin ve motivasyonun arttırılması adına özlük haklarının iyileştirilmesi ile ilgili çalışmalara da öncelik verilmelidir.

\section{Salgın süreciyle ilgili hissettiklerini tek kelime ile özetlerseniz ne söylemek istersiniz?}

Her unvandan bir katılımcıyla yaptığımız görüşmelerde, bu soruya gelen cevaplar esasında katılımcıların kurumsal destekten de uzak kaldıklarını gösterir niteliktedir. Verilen cevaplar şöyledir: "Uzakları yakın etmiş, yorulmuş, bunalmış, memnuniyetsiz, kopukluk, belirsizlik, daralmışlık, bunalmışlı". Üniversitelerin psikolojik danışmanlık birimleri tarafından öğretim elemanlarına da bireysel veya grup olarak psikolojik destek sağlanmalıdır. Ders sırasında öksüren öğrencisine test yaptırmasını tavsiye edip daha sonra aynı öğrencinin enfekte olduğunu öğrenmek, öğrencisinin ders sırasında aile fertlerinden birinin vefat haberini almasına tanıklık etmek (K9), ders anlattığı sırada depreme yakalanmak, öğrencilerini derse devam konusunda meslek hayatında ilk defa gözdağı vermek zorunda kalmak (K11), mikrofonu açık veya kapalı unutma kaygısı (K13) gibi pek çok olay öğretim elemanlarını baskı altında bırakmıștır.

\section{Sonuç}

Covid-19 salgını sonrasında dünyadaki diğer üniversitelerde olduğu gibi Türkiye'de de çok kısa süre içerisinde acil uzaktan eğitim planlamaları yapılmıştır. Dijital kültüre uyum, kurumsal alt yapı ve bakış açısı, öğrenci başarısı ve ölçme değerlendirme, öğretim elemanı açısından cinsiyet başlıkları çevirim içi eğitim döneminin en çok öne çıkan başlıkları olmuştur. Dil ve edebiyat gibi duygu, değer ve kültür aktarımı üzerine kurulmuş alanların eğitiminde de acil uzaktan eğitim eylem planları yapılmıştır. Araştırmamızda da Türk Dili, Türk Dili ve Edebiyatı Eğitimi, Türkçe Eğitimi, Türk Dili ve Edebiyatı bölümlerinde görev yapan öğretim elemanlarının çevirim içi ders sürecindeki algı, tutum ve deneyimlerinin bağlamsallaştırılması amaçlanmıştır. İlgili bölümlerden 21 öğretim elemanı ile anket ve görüşme yoluyla toplanan veriler, nitel olarak yorumlanmıștır.

Araştırmaya katılan öğretim elemanlarını \%38'inin uzaktan eğitim kavramıyla uygulamalı olarak salgın sürecinde tanıştığı görülmektedir. Katılımcıların \%76'sı da salgın öncesinde uzaktan eğitim yoluyla ders vermediğini belirtmiştir. Ev ortamının, uzaktan eğitim yoluyla aldıkları eğitimin verimine -bireysel farklılıklar nedeniyle- etki ettiği görülmüştür. Ulaşım kolaylığı, mekân sınırlarının ortadan kalkması ve pratiklik gibi unsurlar nedeniyle uzaktan eğitim yoluyla aldıkları eğitimden verim alabildiklerini belirtmişlerdir.

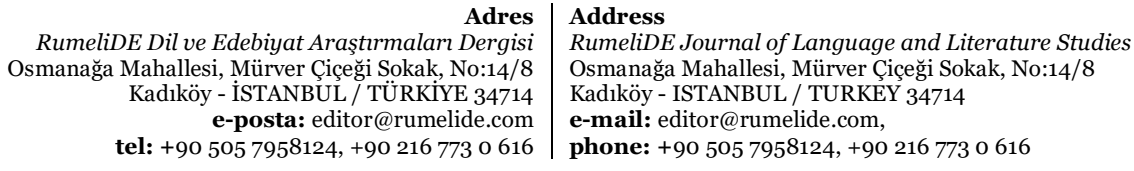


Katılımcıların dijital okuryazarlık seviyeleri arasında büyük farklılıklar vardır. Çevirim içi derslerde kullanabilmek için çevirim içi ders uygulamaları eğitimi aldığını söyleyen veya 10 'dan fazla dijital uygulama kullanan öğretim üyesi olduğu gibi akıllı telefon kullanmadığını belirten öğretim üyesi de vardır.

Uzaktan eğitimle verilen derslerde katılımcıların \%81'i teknik problem yaşadığını, \%18'i ise yaşamadığını belirtmiştir. En çok yaşanan teknik problemler sırasıyla internet kopması/yavaşlaması (\%38), kullanılan çevirim içi sistemden kaynaklanan sorunlar (\%24), elektrik kesintisi (\%10), cihaz sorunu (\%10)'dur. Katılımcıların derslerinde teknik problem yaşadıklarında sıklık sırasına göre ders telafisi; teknik birimlerden destek isteme; kendi tecrübesiyle sorunu yönetmek; farklı bir çevirim içi program kullanımı; e-posta, Whatsapp, Telegram gibi iletişim yollarını kullanmak; gecikme ve ders iptali gibi çözüm yolları buldukları görülmektedir.

Katılımcıların tamamı teknolojiye dair yeni şeyler öğrenmekten keyif aldıklarını belirtseler de ani gelişen uzaktan eğitimin bu keyfi ortadan kaldırdığını belirtenler de vardır. Ayrıca bu yeni öğrenme ortamında uzun süre ekrana bağlı kalınmasının tükenmişlik hissi yarattığından da bahsetmişlerdir.

İletişim ve ölçme değerlendirme konuları çevirim içi eğitimin en büyük sınırlılığı olarak belirtilmiştir. Öğretmenlik mesleğinde rol modele ihtiyaç duyulması, yaparak yaşayarak öğrenme ve mesleki kimlik edinme konuları da çevirim içi eğitimin sınırlılı̆ıı olarak sıkça dile getirilmiştir. Sınırılık yaşandığı belirtilen ilk üç ders; öğretmenlik uygulaması-okul deneyimi, yazılı anlatım ve sözlü anlatımdır. Mekân birliği ve zaman tasarrufu sağlaması, dijital kaynakların ve uygulamaların kullanımının, paylaşımının kolaylaştırılması balıkları da çevirim içi eğitimin yararlılıkları başlığı altında belirtilmiştir. Çevirim içi eğitim sürecinde, teorik derslerin eğitiminde yararlılıklar elde edildiği belirtilmiştir.

Katılımcılar tarafından çevirim içi derslerde, ders sonrasında, ders malzemesi hazırlamak için kullanılan 28 uygulama ismi verilmiştir. Kadın öğretim elemanlarının, erkek öğretim elemanlarından daha fazla uygulama kullandığı görülmüștür. 20-40 yaş aralığındaki öğretim elemanları, 40-60 yaş aralığındakilere göre neredeyse 2 kat fazla dijital uygulama kullanmaktadır. Microsoft Office uygulamaları dışında en çok kullanılan ilk üç uygulama; Padlet, Kahoot ve Edmodo'dur. Cep telefonlarında kullandıklarını belirttikleri ilk üç uygulama; Zoom, YouTube ve Teams'dir.

Salgın döneminde verilen eğitimde akademik başarının arttığını belirten öğretim elemanı yoktur. Katılımcıların \%67'si salgınla birlikte akademik başarının düștüğünü, \%76'sı öğrenci performanslarından memnun olmadığını söylemiştir. Akademik başarının düştüğünü söyleyen katılımcıların \%33'ü ise çevirim içi sınavların ölçme ve değerlendirme problemine dikkat çekmiştir. Akademik başarının anlamlı olabilmesi için ölçme değerlendirmenin güvenilir olması gerektiği de vurgulanmıştır. Tüm bunlara rağmen katılımcların \%62'si, salgın günlerinden sonra çevirim içi eğitim vermek istediklerini belirtmişlerdir. Mekân birliğinin ve zaman tasarrufunun sağlanmış olması öğretim elemanlarına cazip geldiği de görülmektedir.

Katılımcıların \%71'i çevirim içi eğitim sürecinde cinsiyet faktörünün öğretim elemanının başarısını etkileyen bir unsur olmadığını belirtmiştir. Ancak bu cevabı veren öğretim elemanlarının erkek veya bekâr kadın öğretim elemanları oldukları görülmektedir. Katılımcıların \%29'u kadın akademisyenlerin "annelik" sorumluluklarına dikkat çekmiștir. Çevirim içi eğitim sürecinde, anne olan öğretim elemanlarının olumsuz yönde etkilendikleri görülmektedir.

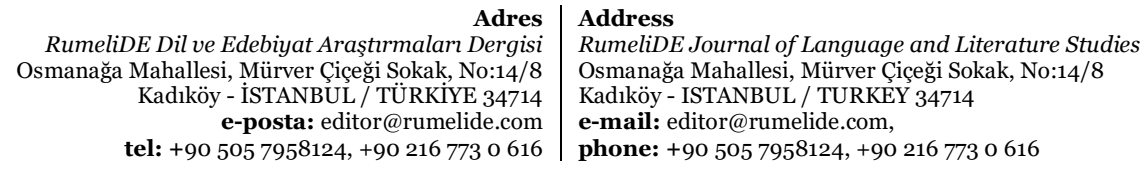


Katılımcıların salgın öncesinde bir günde bilgisayar başında geçirdiği ortalama süre 4 saat iken, salgın sonrasında bu süre ortalama 8 saate çıkmıştır. Bu durumun öğretim elemanlarının beden ve ruh sağlı̆̆ına yansıdığı da görülmektedir. Göz yorgunluğuna, tükenmişlik hissine, bunalmışlığa, yorgunluğa ve memnuniyetsizliğe dair pek çok problem belirtilmiştir.

Katılımcıların \%48'i salgın sürecini kurumlarının başarılı bir şekilde yürüttügünü, \%24'ü sürecini başarılı biçimde yürütemediğini belirtmiştir. Katılımcıların \%42'si kendi cihazlarını kullandıklarını belirtmiştir. Ayrıca katılımcıların \%29’u ek ders ödemelerini salgın öncesi dönemle aynı koşullarda almadıklarını; ek ders ödemelerinin gecikmeli yatırılması, yarısının yatırılması, sınıfların birleștirilmesiyle ücret düşüşü gibi problemler yaşandığı belirtilmiştir.

Salgın sürecinde özlük haklarında gerileme yaşayıp yaşamadıkları sorulduğunda, katılımcıların \%62'si "Hayır" cevabı verirken \%29'u "Evet" cevabı vermiştir. Eksik ücretlendirme, kısa/kısmî çalışma ödeneğinden faydalanan bir kurum olması nedeniyle maaşın yarısının farklı zamanlarda İșkur ve üniversite tarafından yatırılması, sigorta priminin salgın başından beri yatırılmaması, sigorta priminin 10 gün üzerinden yatırılması, ek ders ücretlerinin yarıya indirilmesi, mesai saatlerinin ortadan kalkması, maaşın sözleşmede yazan miktarın altında kalması, ücretlerin geç yatırılması gibi problemler dile getirilmiştir. Özlük hakları konusunda gerileme yaşadıklarını belirten öğretim elemanlarının tamamı vakıf üniversitesinde görev yapmaktadır.

Araştırmamızda anket ve görüşme yoluyla toplanan veriler, öğretim elemanlarının psikolojik olarak kendilerini baskı altında ve tükenmiş hissettiklerini de -özellikle anne olan öğretim elemanlarıgöstermektedir.

\section{Öneriler}

Salgın başlangıcında acil uzaktan eğitim olarak başlayan süreçte, alt yapının sağlanması ve ders tasarımlarının yapılması çok hızlı biçimde organize edilmişti. Ancak artık sürecin daha etkili ve titiz biçimde ilerlemesi için kurumların uzaktan eğitim merkezleri, bilgi işlem merkezleri ve fakülte yöneticilerinin ortak planlar yapması gereklidir. Dünyadaki diğer çalışmalar takip edilerek verimliliğin, öğrenci başarısının ve memnuniyetinin arttırılması amaçlanmalıdır.

Çevirim içi derslerdeki ölçme değerlendirme sorunlarının en aza indirilmesi, akademik başarının da daha anlamlı biçimde artmasını sağlayacaktır.

Kurumlar tarafından, öğretim elemanlarına çevirim içi ders tasarımı ve dijital uygulamaların kullanımı ile ilgili eğitimler verilmesi gereklidir. Daha dinamik ve yenilikçi ders tasarımları yapabilmeleri için zorunlu eğitim dönemleri organize edilmelidir.

Duygu, değer ve kültür aktarımının sağlanabilmesi; öğretmenlik mesleğinin temel prensiplerinin verilebilmesi için tek taraflı anlatıma dayalı derslerden ziyade öğrencinin merkeze alındığı, etkileşimli ders tasarımlarının yapılması sağlanmalıdır. Ders tasarımları, kurumlar tarafından denetlenmelidir.

Salgın sürecinde ve sonrasında anne olan öğretim elemanlarına kurumsal destek ve çalışma planında esneklik sağlanmasına yönelik çalışmalar yapılmalıdır.

Araştırmamızda vakıf üniversitelerinde görev yapan öğretim üyelerinin özlük haklarında salgın sürecinde çok daha büyük bir gerileme yaşandığı ortaya konulmuştur. Bu durumun öğretim elemanının

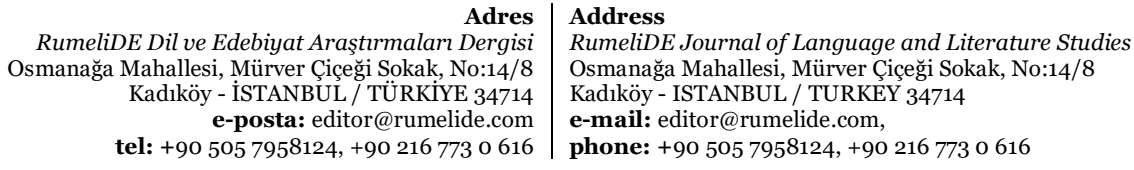


motivasyonuna, kurumsal aidiyetine ve verimliliğine etki etmesi de kaçınılmazdır. Yükseköğretim Kurumunun, salgın sürecinde vakıf üniversitelerinde görev yapan öğretim elemanlarının özlük haklarına dair daha sıkı denetlemeler yapması ve kurumlara yaptırımlar getirmesi gerekmektedir.

Kurumların psikolojik danışmalık birimlerinin, öğretim elemanlarına da destek verebilmesi için eğitimler, seminerler ve kişisel terapi seansı planlamaları yapmaları da bu süreçte büyük önem arz etmektedir.

\section{Kaynakça}

Ahlburg, D. A. (2020). COVID-19 and UK universities. The Political Quarterly, 91(3), 649-654.

Akgün, A. İ. (2020). COVID-19 sürecinde acil durum uzaktan eğitimi yoluyla verilen muhasebe eğitimine yönelik öğrenci görüşleri. Açıköğretim Uygulamaları ve Araştırmaları Dergisi, 6(4), 208-236.

Alon, T., Doepke, M., Olmstead-Rumsey, J., \& Tertilt, M. (2020). The impact of COVID-19 on gender equality (No. w26947). National Bureau of economic research.

Atasoy, R., Özden, C., \& Kara, D. N. (2020). Covid-19 pandemi sürecinde yapılan E-ders uygulamalarının etkililiğinin öğrencilerin perspektifinden değerlendirilmesi. Electronic Turkish Studies, 15(6).

Baran, E., Correia, A. P., \& Thompson, A. (2011). Transforming online teaching practice: Critical analysis of the literature on the roles and competencies of online teachers. Distance Education, 32(3), 421-439.

Bayburtlu, Y. S. (2020). Covid-19 pandemi dönemi uzaktan eğitim sürecinde öğretmen görüşlerine göre Türkçe eğitimi. Electronic Turkish Studies, 15(4).

Blume, C. (2020). German teachers' digital habitus and their pandemic pedagogy. Postdigital Science and Education, 2(3), 879-905.

Creswell, J. W. (2015). Nitel araștırma yöntemleri [Qualitative research methods](M. Bütün \& SB Demir, Trans. Eds.). Ankara: Siyasal.

Ertuğ, C. A. N. (2020). Coronavirüs (Covid-19) pandemisi ve pedagojik yansımaları: Türkiye'de açık ve uzaktan eğitim uygulamaları. Açıköğretim Uygulamaları ve Araştırmaları Dergisi, 6(2), 11-53.

From, J. (2017). Pedagogical Digital Competence--Between Values, Knowledge and Skills. Higher Education Studies, 7(2), 43-50.

Hodges, C., Moore, S., Lockee, B., Trust, T., \& Bond, A. (2020). The difference between emergency remote teaching and online learning. Educause review, 27(1), 1-9.

Glesne, C. (2013). Nitel araştırmaya giriş. Anı Yayıncılık.

Krumsvik, R. J. (2008). Situated learning and teachers' digital competence. Education and information technologies, 13(4), 279-290.

Malisch, J. L., Harris, B. N., Sherrer, S. M., Lewis, K. A., Shepherd, S. L., McCarthy, P. C., ... \& Deitloff, J. (2020). Opinion: In the wake of COVID-19, academia needs new solutions to ensure gender equity. Proceedings of the National Academy of Sciences, 117(27), 15378-15381.

Minello, A. (2020). The pandemic and the female academic. Nature, 17, 2020.

Ng, W. (2012). Can we teach digital natives digital literacy?. Computers \& education, 59(3), 1065-1078.

O'Neil, M. L., Aldanmaz, B., Quirant Quiles, R. M., Rose, N., Altuntaş, D., Tekmen, H., \& Kar, A. (2019). Türkiye'de Yükseköğretimdeki Cinsiyet Eşit (siz) liği: 1984-2018. Kadir Has University.

Pinho-Gomes, A. C., Peters, S., Thompson, K., Hockham, C., Ripullone, K., Woodward, M., \& Carcel, C. (2020). Where are the women? Gender inequalities in COVID-19 research authorship. BMJ Global Health, 5(7), e002922.

Saban, A., Ersoy, A., Özden, M., Bozkurt, M., Ersoy, A., Akar, H., \& Yahşi, Z. (2017). Eğitimde nitel araştırma desenleri. Anı Yayıncllı

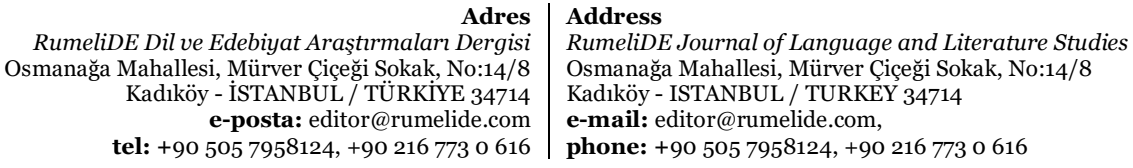


Soetaert, R., \& Bonamie, B. (1999). Reconstructing the Teaching of Language: a view informed by the problems of traditional literacy in a digital age.Journal of Information Techology for Teacher Education, 8(2), 123-147.

Yolcu, H. H. (2020). Koronavirüs (Covid-19) Pandemi sürecinde sınıf öğretmeni adaylarının uzaktan eğitim deneyimleri. Açıköğretim Uygulamaları ve Araştırmaları Dergisi, 6(4), 237-250.

Yücel Çetin, A. (2019). Sözlü gelenekten elektronik ortama halk hikâyelerinde anlatıcı tipolojisi. 9.Milletlerarası Türk Halk Kültürü Kongresi Bildirileri. T.C. Kültür ve Turizm Bakanlığı Araştırma ve Eğitim Genel Müdürlüğü

Yükseköğretim Kurumu, Vakıf Öğretim Kurumları Raporu, Ankara 2021

Adres
RumeliDE Dil ve Edebiyat Araştırmaları Dergisi Osmanağa Mahallesi, Mürver Çiçeği Sokak, No:14/8 Kadıköy - İSTANBUL / TÜRKIYE 34714 e-posta: editor@rumelide.com tel: +90 $5057958124,+902167730616$
Address

RumeliDE Journal of Language and Literature Studies Osmanağa Mahallesi, Mürver Çiçeği Sokak, No:14/8

Kadıköy - ISTANBUL / TURKEY 34714

e-mail: editor@rumelide.com

phone: +90 $5057958124,+902167730616$ 